\title{
MetA-AnAlysis of THE Business CyCle CORRELATION BETWEEN THE EURO AREA AND THE CEECS
}

\author{
JARKO FIDRMUC \\ IIKKA KORHONEN
}

\author{
CESIFO WORKING PAPER NO. 1693 \\ CATEGORY 6: MONETARy POLICY AND INTERNATIONAL FinANCE \\ MARCH 2006
}

An electronic version of the paper may be downloaded

- from the SSRN website:

wWw.SSRN.com

- from the CESifo website: www.CESifo-group.de 


\title{
META-ANALYSIS OF THE Business CYCLE CORRELATION BETWEEN THE EURO AREA AND THE CEECS
}

\begin{abstract}
We review the literature on business cycle correlation between the euro area and the Central and Eastern European countries (CEECs), a topic that has gained attention as the newest EU members approach monetary union. Our meta-analysis of 35 identified publications suggests some CEECs already have comparably high correlation with the euro area business cycle. We find that estimation methodologies can have a significant effect on correlation coefficients. While CEEC central bankers tend to be more conservative in their estimates than academics or eurosystem researchers, we find no evidence of a geographical bias in the studies.
\end{abstract}

JEL Code: C42, E32, F15, F31.

Keywords: monetary union, optimum currency area, business cycles, meta analysis.

\author{
Jarko Fidrmuc \\ University of Munich \\ Department of Economics \\ Geschwister-Scholl-Platz 1 \\ 80539 Munich \\ Germany \\ jarko.fidrmuc@Irz.uni-muenchen.de
}

\author{
Iikka Korhonen \\ Institute for Economies in Transition \\ Bank of Finland \\ PO Box 160 \\ 00101 Helsinki \\ Finland \\ Iikka.korhonen@bof.fi
}

\section{March 2006}

We are grateful to Jukka Pirttilä, Maria Antoinette Silgoner, Anna Czogała, Julius Horvath, Markus Knell, and Eduard Hochreiter for their comments. The views expressed in this paper are those of the authors and do not necessarily represent the position of the Bank of Finland. The usual disclaimer applies. 


\section{Introduction}

Soon after the European Union's Eastern Enlargement in May 2004, several new member states joined the Exchange Rate Mechanism II (ERM II). At present, seven new states participate in the ERM II, and the remaining new member countries and potential EU members Bulgaria and Romania are all expected to join in the coming years. ${ }^{1}$ Thus, it is possible that new member states, after completing their mandatory two-years in ERM II, could introduce the euro in their own countries as soon as 2007.

In the paper, we take stock of the growing literature on business cycle correlation between the countries of the Central and Eastern Europe (Bulgaria, the Czech Republic, Estonia, Hungary, Latvia, Lithuania, Poland, Romania, Slovakia, and Slovenia), and the euro area. The optimum currency area (OCA) theory states that a high degree of business cycle synchronization should be an important criterion for participation in a monetary union. This criterion is generally applied to questions related to euro adoption and exchange rate regimes in the new member states of the EU, as well as to other countries having intensive trade and economic relations with the EU (including prospects for eventual EU membership).

On one hand, the CEECs are relatively small when compared to the euro area and generally expected to be strongly affected by the business cycle of their most important trading partner, the euro area. On the other hand, these countries are likely to benefit disproportionately from EU integration and introduction of the euro, reflecting the relative economic size of the regions. Given these contradictory expectations, the authors have applied a range of methodologies and sample periods in measurement of recent business cycles.

Economic analysis of CEECs is inherently characterized by significant data problems. In general, reliable time series are available only from the beginning of the 1990s, and for some countries the availability of data is even more limited. Data comparisons of multiple sources often show significant differences, and frequent data revisions may make replications of analyses difficult. As a result, the robustness of results reported in any particular study should be questioned.

Of course, such data problems are nothing unfamiliar to researchers in other fields in the natural and social sciences. Meta-analyses of existing studies have been suggested as a

\footnotetext{
${ }^{1}$ Estonia, Latvia and Slovenia joined the ERM II in June 2004, Latvia, Malta and Cyprus in April 2005, and Slovakia in November 2005. Bulgaria has a currency board against the euro and is likely to join the ERM II after its accession to the EU in 2007 or 2008.
} 
potentially fertile way to gain more robust results (Lipsey and Wilson, 2001). Meta-analyses, which basically summarize published results on particular topics, provide an aggregate overview of a subject and allow analysis of factors that may influence the results such as data definition, time period, or author characteristics. The use of meta-analysis has recently become a popular economics research tool (e.g. Stanley, 2001; Stanley and Jarrell, 2005), most notably in monetary economics (De Grauwe and Costa Storti, 2004; Rose and Stanley, 2005; and Knell and Stix, 2005). Thus, meta-analysis provides the means to extend analysis beyond standard literature surveys.

The paper is structured as follows. The next section reviews the optimum currency area theory from the point of view of the new member states. Section 3 presents a metaanalysis of 35 publications with more than 450 point estimates of business cycle correlation between the CEECs and the euro area. Section 4 concludes.

\section{Literature review}

The optimum currency area theory originates with Mundell (1961), who proposed that a country would find it advantageous to peg the external value of its currency to a another country's currency when the business cycles of the two countries were highly correlated. ${ }^{2}$ While this correlation is never perfect in practice, the problem of asymmetric shocks is alleviated as long as factors of production are able to move between the countries (or regions). Fiscal policy and flexible labor markets can also be used in lieu of traditional adjustment channels. Following the breakdown of the Bretton Woods system, OCA analysis was regularly applied in many countries in assessing the desirability of adopting a fixed exchange rate.

The OCA theory enjoyed a revival of sorts in the run-up to the euro. Empirical studies of the period typically assess the correlations between the German business cycle and those of other potential member countries. The influential contribution of Bayoumi and Eichengreen (1993) recovers the underlying supply and demand shocks in the prospective members of the monetary union using a technique developed by Blanchard and Quah (1989). The

\footnotetext{
${ }^{2}$ Risk insurance mechanisms within a monetary union could potentially reverse the results. Demyanyk and Volosovych (2004) conclude that those countries facing most asymmetric business cycles may gain most from risk-sharing. This idea goes back to Kalemli-Ozcan et al. (2001) and Mundell (1973). See also MacKinnon (2002) for more general discussion of risk-sharing implications for the OCA theory.
} 
unobservable shocks are identified with the help of a restriction that the long-term impact of demand shocks on output is zero, while supply shocks are assumed to have a permanent effect on output.

A third wave of interest in OCA analyses was generated when it became clear that new EU members would participate in the monetary union. While papers on the topic apply various methods to reach different results, most find that the business cycles in several new member states are about as synchronized with the euro area as several of the peripheral members of the euro area. Unfortunately, there is also a considerable uncertainty with respect to the robustness of the results.

Table 1 lists papers that assess the correlation of business cycles of the CEECs with the euro area business cycle (or a proxy thereof). It is immediately apparent that this topic has been approached from many different angles. Several contributions utilize the structural VAR approach. Many simply look at the cyclical variation around an estimated trend (usually trend of industrial production).

Availability of data places obvious limits on testing options. A frequent criticism of meta-analysis in summarizing results on a given topic is that all papers are given equal weights in determining the outcome. On the other hand, ranking the studies according to quality of contribution runs the risk of being overly subjective. While papers may have been published in journals, thus assuring a certain quality level, it may not be particularly significant in an emerging sub-field such as study of CEECs. It is quite likely that important papers are still in the refereeing process. Furthermore, most studies, including some the most influential ones, fail to specify clearly the number of observations; information that would be useful in weighting the results. Following the convention of meta-analyses in the field (Égert and Halpern, 2006), we thus give all estimates equal weight.

We identify two major categories of papers on business cycle coordination between the euro area and the CEECs. In the first category, papers look at correlations of a detrended indicator of aggregated output. Business cycle coordination is analyzed mainly from the perspective of international transmission of business cycles. In addition to first or seasonal differences, several authors apply various filters (e.g. Hodrick-Prescott or Band-Pass filters), or use time-series models. In the second category, VARs, particularly structural VARs, are used to recover underlying shocks with properties derived from the economic theory. While the first approach prevailed in early analysis (and in papers using business cycle synchronization in further analysis), structural VARs dominate current research approaches. 


\section{Table 1: Surveyed studies}

\begin{tabular}{|c|c|c|c|c|}
\hline Authors & Countries & Method & Frequency & $\begin{array}{c}\text { Reference } \\
\text { country }\end{array}$ \\
\hline Boone and Maurel (1998) & CZ,HU,PL,SI & HP Filter (UR and IP) & monthly & Germany \\
\hline Frenkel et al. (1999) & CE5,BG,EE,LV & Supply and demand shocks & quarterly & Germany \\
\hline Horvath (2000) & CE5,B3 & Supply and demand shocks & quarterly & Germany \\
\hline Korhonen $(2001,2003)$ & $\mathrm{CE} 5, \mathrm{~B} 3, \mathrm{RO}$ & VAR (correlation of IRF) & monthly & Euro area \\
\hline Fidrmuc, Korhonen $(2001,2003)$ & CE10 & Supply and demand shocks & quarterly & Euro area \\
\hline Fidrmuc $(2001,2004)$ & CE10 & Correlation (GDP and IP) & quarterly & Germany \\
\hline IMF (2000) & CE10 & Correlation (GDP and inflation) & annually & Germany \\
\hline Borowski (2001) & $\mathrm{PL}$ & Correlation of IP growth rates & monthly & Germany \\
\hline Babetskii et al. $(2002,2004)$ & CE5,EE,LV,RO & $\begin{array}{l}\text { Supply and demand shocks } \\
\text { (Kalman filter) }\end{array}$ & quarterly & EU15 \\
\hline Buiter and Grafe (2002) & CZ,EE,HU,PL,SI & Correlation of inventory changes & annually & Germany \\
\hline Csajbók and Csermely (2002) & CE4 & Supply and demand shocks & quarterly & euro area \\
\hline Boreiko $(2002,2003)$ & CE10 & HP Filter (IP) & monthly & Germany \\
\hline Frenkel, Nickel $(2002,2005)$ & CE5,BG,EE,LV & Supply and demand shocks & quarterly & euro area \\
\hline Backé et al. (2003) & CE10 & HP Filter (inflation) & monthly & euro area \\
\hline Błaszkiewicz, Wozniak (2003) & CE5,B3 & Correlation (GDP) & quarterly & euro area \\
\hline EFN (2003) & CE5,B3 & Supply, demand, monetary shocks & quarterly & euro area \\
\hline Horníková (2003) & $\mathrm{CZ}$ & SVAR (IP, inflation, money) & monthly & euro area \\
\hline Luikmel, Randveer (2003) & $\mathrm{EE}$ & HP Filter (GDP) & quarterly & euro area \\
\hline Süppel (2003) & CE5,B3 & Supply and demand shocks & quarterly & EU15 \\
\hline Lättemäe (2003) & CE5,B3 & Supply, demand, monetary shocks & quarterly & euro area \\
\hline Artis et al. (2004) & $\mathrm{CE} 5, \mathrm{~B} 3$ & HP Filter (IP) & monthly & euro area \\
\hline Backé et al. (2004) & CE5,B3 & Supply and demand shocks & quarterly & euro area \\
\hline Babetskii (2004) & CE5,EE,LV,RO & $\begin{array}{l}\text { Supply and demand shocks } \\
\text { (Kalman filter) }\end{array}$ & quarterly & EU15 \\
\hline Barrell and Holland (2004) & CZ,HU,PL & Macro model (NiGEM) & quarterly & Germany \\
\hline Berger et al. (2004) & $\mathrm{CE} 5, \mathrm{~B} 3, \mathrm{RO}$ & HP Filter (IP) & monthly & euro area \\
\hline Fidrmuc and Korhonen (2004) & $\mathrm{CE} 5, \mathrm{~B} 3, \mathrm{BG}$ & Supply and demand shocks & quarterly & euro area \\
\hline Fidrmuc and Hagara (2004) & $\mathrm{CE} 5, \mathrm{~B} 3, \mathrm{BG}$ & Supply and demand shocks & quarterly & euro area \\
\hline Horvath and Rátfai (2004) & CE5,B3 & Supply and demand shocks & quarterly & Germany \\
\hline Karmann and Weimann (2004) & CE5, B3 & Supply and demand shocks & quarterly & Germany \\
\hline Ramos and Suriñach (2004) & CE5,B3 & Supply, demand, monetary shocks & quarterly & euro area \\
\hline Traistaru (2004) & $\mathrm{CE} 5, \mathrm{~B} 3$ & HP filter (GDP) & quarterly & euro area \\
\hline Darvas, Szapáry (2005) & CE5,B3 & HP Filter (GDP) & quarterly & euro area \\
\hline Darvas, Vadas (2005) & CE5,B3 & Five different filters (GDP) & quarterly & euro area \\
\hline Demyanyk, Volosovych (2005) & CE5,B3 & Correlation of GDP growth rates & quarterly & EU25 \\
\hline Eickmeier and Breitung (2005) & $\mathrm{CE} 5, \mathrm{~B} 3$ & Dynamic correlation (GDP, CPI) & quarterly & euro area \\
\hline
\end{tabular}

Key: CE4 -Czech Republic, Hungary, Poland, and Slovakia CE5 - CE4 and Slovenia, B3 - Estonia, Latvia and Lithuania, BG - Bulgaria, CZ -Czech Republic, EE - Estonia, HU - Hungary, LV - Latvia, LT - Lithuania, PL Poland, RO - Romania, SI - Slovenia. CE10 - all countries. 


\subsection{Statistical approach}

Analysis of simple correlations prevails in the early research. For example, the IMF (2000) presents a relatively high degree of business cycle synchronization between Germany and the CEECs. Similarly, Buiter and Grafe (2002) present correlations of inventory changes as a more appropriate indicator than aggregate GDP.

Furthermore, the majority of papers that apply more advanced statistical tests start with a short look at the properties of raw data, which, as Fidrmuc and Korhonen (2003) note, may be misleading. In general, we find rather high correlations between various groups of countries. In particular, EU countries are strongly correlated with the US. One interpretation is that there is no independent European cycle, which contradicts previous results (see Artis and Zhang, 1997). As a result, the increased degree of business cycle synchronization within the EU (and possibly also between the euro area and the new member states) is consistent with the globalization rather than with the Europeanization. This result is confirmed also for various statistical filters (Artis, 2003a). In contrast, structural VARs reveal underlying shocks, which are more different between Europe and the US (Fidrmuc and Korhonen, 2003).

Finally, several authors use simple correlations of business cycles for further analysis. Fidrmuc (2001 and 2004) and Maurel (2002) rely on the endogeneity hypothesis of optimum currency area criteria set out in Frankel and Rose (1998). Fidrmuc demonstrates that the convergence of business cycles relates to intra-industry trade, but finds no significant relation between business cycles and bilateral trade intensity. He further finds that the business cycle (defined as detrended industrial production) strongly correlates with the German cycle in Hungary and Slovenia (and Poland to a lesser extent). Given the high degree of intra-industry trade, he identifies a significant potential for increasing the correlation between business cycles in the EU and the new member states (Hungary, Slovenia, Poland, the Czech Republic, and Slovakia). Maurel (2002) also presents evidence that intra-industry trade increases the symmetry of business cycles. This is relevant if one believes that a higher per capita GDP in the new member states will be associated with more intra-industry trade.

Boreiko (2003) uses correlation of business cycles as an indicator (his others pertain to fulfillment of Maastricht criteria) for fuzzy cluster analysis. He compares simple correlation of growth rates for industrial production and for the Hodrick-Prescott trend. Both methods produce comparable results, although the latter approach leads to slightly higher values (preferred estimates). 
Some studies use different measures of correlation between business cycles in the euro area (or the EU) and the CEECs. Boone and Maurel (1998) calculate correlation coefficients between the cyclical components of industrial production and unemployment rates for selected CEECs (Baltic states are excluded) against Germany and the EU. Cyclical component of the business cycle indicators is derived with the help of Hodrick-Prescott filter. They generally find a relatively high degree of business cycle correlation for the CEECs with Germany, higher than e.g. for Portugal or Greece. This implies relatively low costs for giving up monetary sovereignty and entering a monetary union with Germany.

Boone and Maurel (1999) abandon the methodology used in their earlier work to assess the similarity between business cycles in selected CEECs (Czech Republic, Hungary, Poland, and Slovakia) against Germany and the EU. They fit a time-series model for the unemployment rate in an accession country using EU (German) unemployment shocks derived in a separate regression. Under this framework, they start by asking how large a share of the variation in the unemployment rate can be explained by German or EU-wide shocks. They then look at correlation in the propagation of the shock. Boone and Maurel find that the share of variation explained by the German shocks is fairly high for all analyzed countries and highest for Hungary and Slovakia. The countries with the highest correlations of responses to a German shock are Poland and Slovakia. Boone and Maurel conclude that the business cycles in these countries are close enough to the German cycle so that participating in the monetary union would bring net benefits.

Barrell and Holland (2004) compare residuals of estimated employment in a largescale macroeconomic model of the world economy (including the Czech Republic, Hungary, and Poland). Positive correlation is interpreted as coordination of reallocation activities between the countries. Between 1993 and 2002, only Hungary has a high degree of correlation with Germany, while the Czech Republic and Poland are negatively correlated.

Artis et al. (2004) and Darvas and Szapáry (2005) describe the business cycle of the CEECs. These papers prefer the Band-Pass filter to structural VARs for robustness reasons. Furthermore, Artis et al. (2004) put the focus on the identification of the individual business cycles. They find that Hungarian and Polish business cycles are generally the most similar to the euro area cycle. Darvas and Szapáry (2005) differ from most other contributions in the area in that they investigate the behavior of several expenditure and sectoral components of GDP. They find that GDP, industrial production and exports in Hungary, Poland, and Slovenia have achieved a reasonably high degree of correlation with the euro area. However, 
private consumption and services are not highly correlated in these three countries, and in the other new EU member countries, the level of correlation is even lower. Darvas and Szapáry also assess whether the correlation of CEECs with the euro area has increased over time. Again, results are somewhat inconclusive. In approximately half of the countries, correlation of GDP cycle has increased; in the other half, it has decreased.

Several studies attempt to test whether the correlation of business cycles has changed over time. Artis et al. (2004) look not only at overall correlation but also at moving correlation of business cycles computed as deviations from HP band-pass cycles, where the moving window of approximately three years gives lower weights to observations more distant from time $t$.

\subsection{Vector Autoregression Models}

As data quality improved with the progress of economic transition in the CEECs, authors found it possible to use VAR and structural VAR for the assessment of business cycles in the CEECs and the euro area. Among the earliest studies in this group, Korhonen (2003) examines monthly indicators of industrial production in the euro area and nine CEECs. The issue of correlation is assessed with the help of separate VARs for the first difference of the euro-area production and production in each of the analyzed countries. The correlation of impulse responses to a euro-area shock is taken as evidence of symmetry of the business cycles. Korhonen finds that some CEECs (especially Hungary) exhibit a high correlation with the euro-area business cycle. Correlation seems to be at least as high as in some smaller EMU members (e.g. Portugal and Greece).

Frenkel et al. (1999), Frenkel and Nickel (2002), Fidrmuc and Korhonen (2003, 2004), Süppel (2003), Backé et al. (2004), as well as Fidrmuc and Hagara (2004) use an approach similar to that of Bayoumi and Eichengreen. They recover quarterly supply and demand shocks for various countries, including most CEECs. In some respects, the discussion of new members' business cycle correlation has come full circle with a return to the methods once applied to studies of the euro's feasibility.

Frenkel et al. (1999) find that the correlation between shocks in the euro area and in the nonparticipating EU member states is quite high - as it is for the remaining EFTA countries. The correlation of shocks is quite different between the euro area (proxied by Germany and France) and the CEECs. Unfortunately, there are difficulties in interpreting the results. Perhaps the most serious caveat relates to data used for estimation. Frenkel et al. use quarterly data from the first quarter of 1992 to the second quarter of 1998 . The time period is 
quite short - a problem that really cannot be avoided in such studies. More importantly, the first two or three years in the sample belong to the period of transformational recession for some CEECs, i.e. output losses relate to the change in the economic system. This can make the interpretation of economic shocks problematic. Frenkel and Nickel (2002) use a longer sample, although for a smaller set of comparative countries.

Csajbók and Csermely (2002) estimate supply and demand shocks for a fairly long period (1992-2000). The comparative country is derived as the principal component for EU countries, which possibly may cause deviations between their results and those of other studies. Most importantly, the Czech Republic displays the highest correlation of both demand and supply shocks, while the previous studies show zero or even negative correlation of both types of shocks.

More recently, Ramos and Suriñach (2004) introduce monetary shocks with structural VAR models. ${ }^{3}$ The authors discuss two possible ways to include monetary shocks: either real interest rates (following Artis, 2003), or real effective exchange rate (similar to Clarida and Galí, 1994), to the structural VAR model of the previous variables (growth and inflation). For data reasons, the second model was estimated for only four new member states (Czech Republic, Hungary, Poland, and Slovakia). Surprisingly, the monetary shocks implied by the Artis decomposition are very similar for the CEECs and the euro area. Correlation coefficients (computing for three two-year windows) reach 0.78 in the case of Hungary (2001-2002). The Czech Republic and Poland during the currency float (1998-2000) also display high positive correlations (above 0.5 in both cases). In fact, no CEECs show negative correlations between 1998 and 2002. This counterintuitive result contrasts sharply with the alternative decomposition for the four Visegrad countries, which imply very low or even negative correlation of monetary shocks with the euro area between 1998 and 2002.

Ramos and Suriñach also estimate a structural VAR for the longest available period (1995-2002), computing correlation of supply, demand and monetary shocks for three twoyear windows. Their results show a lower degree of synchronization of business cycles at the

\footnotetext{
${ }^{3}$ Borghijs and Kuijs (2004) estimate three-variable structural VARs for the Czech Republic, Hungary, Poland, Slovakia and Slovenia, although they are not concerned with the correlation of shocks vis-à-vis the euro area. The estimated VARs use monthly data on industrial production, inflation, and real exchange rate against the euro. From the estimations, they derive supply, real demand and money shocks, and conclude that nominal exchange rates have not been particularly useful as shock buffers in the five CEECs - and, in fact, have amplified the effect of money shocks.
} 
end of 1990s, followed by apparent improvements in the early years of this decade. Eickmeier and Breitung (2005) estimate a structural VAR with three different shocks (supply, demand, and monetary policy shocks) and assess how common European shocks are transmitted in the new member countries.

In contrast to the extension of estimations to more types of shocks, other authors use longer time series to analyze the stability of the results between early and late transition periods. Babetskii et al. $(2002,2004)$ use a Kalman filter to estimate time-varying correlation coefficients for supply and demand shocks in the CEECs vis-à-vis shocks in the EU and Germany. They find that the correlation of demand shocks increased during the 1990s, whereas correlation of the supply shocks did not increase to the same degree. Korhonen (2003) estimates correlation of impulse functions from two-variable VARs for two separate sub-periods (1992-1995 and 1996-2000), finding that the correlation of business cycles clearly increased in the second half of the 1990s in the Czech Republic, Hungary, and Slovenia. These results suggest that increasing integration of the CEECs with the EU has increased business cycle correlation and may continue to do so in the future.

A related strand of literature looks at the convergence of level of economic activity (and prices) between the CEECs and the EU. Although the issue of business cycle correlation is probably more important for monetary policy, long-term convergence (or lack thereof) can also impact the function of a monetary union. Indeed, Kočenda (2001) and Kutan and Yigit (2004) find increasing convergence between the CEECs and the EU.

\section{Results of the meta-analysis}

\subsection{Count analysis}

We are aware of 35 independent studies ${ }^{4}$ that provide altogether more than 450 estimations of business cycle correlation between the euro area (or proxy thereof) and the individual CEECs. To our knowledge, the first two papers on the topic were published in 1998. The number of new papers remained relatively low until 2002 (see Figure 1), then exploded after the announcement of the details of EU enlargement. Refereed journals published the earliest contributions in 2003. In 2004, 11 studies were published, reflecting in part the organization of a conference (EABCN meeting in Vienna) and a journal issue (Journal of Comparative

\footnotetext{
${ }^{4}$ Many papers have been published in several working paper versions and possibly a different journal version. Table 1 reports both the most influential working paper version and journal version. Unless the journal version is clearly updated in comparison to the previous working paper, we use only the journal version for further meta analysis.
} 
Economics) dedicated to the topic. The overwhelming majority of these studies concentrate on the new EU member countries. To this day, few contributions deal with Bulgaria or Romania.

The discussion was initially dominated by participants from the EU15 countries (i.e. older EU members) and was carried on mostly within academic institutions. There were notably few contributions from CEEC central banks. More recently, regional differences have lost importance and eurosystem banks have become intensive contributors to the discussion. Even so, the lack of interaction between academia and the central banks is striking. So far, only a few papers have been co-authored by members of academia and central banks or from the EU15 countries and the CEECs.

A decisive feature of the literature is its relatively broad cross-country focus. We found only three papers focusing on a single country. Most studies cover at least eight, and sometimes all ten, CEECs (Bulgaria and Romania are increasingly omitted in the most recent contributions). Correspondingly, the average number of involved countries is relatively high (7.5). Many studies also estimate business cycle correlations for a number of EU15 countries, which are then used as benchmarks for the new member states.

\section{Figure 1: Number of publications}

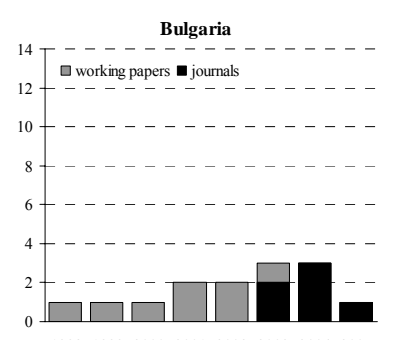

19981999200020012002200320042005

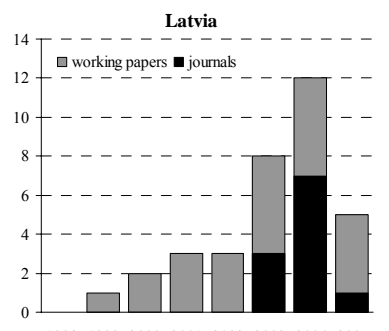

19981999200020012002200320042005

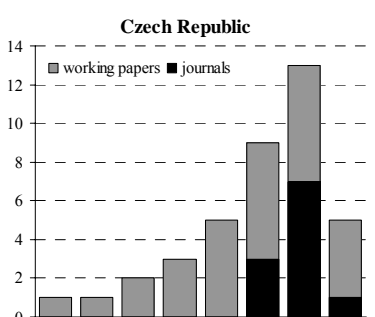

19981999200020012002200320042005

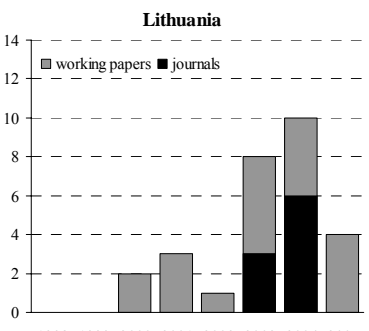

19981999200020012002200320042005

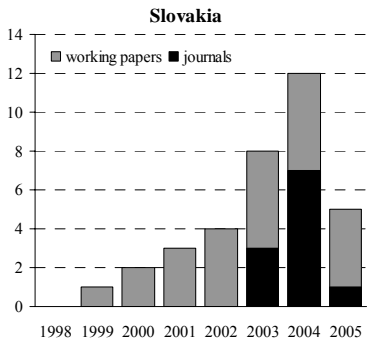

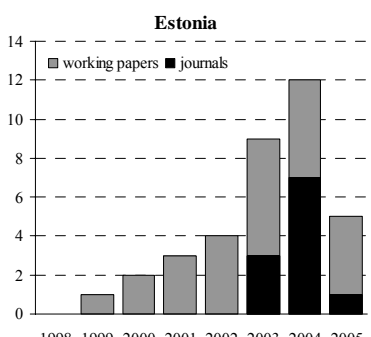

19981999200020012002200320042005

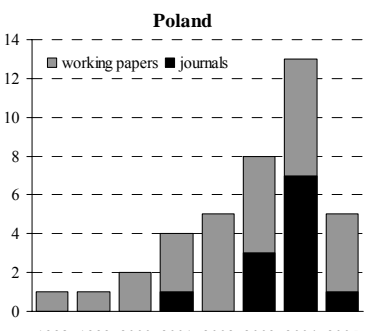

19981999200020012002200320042005

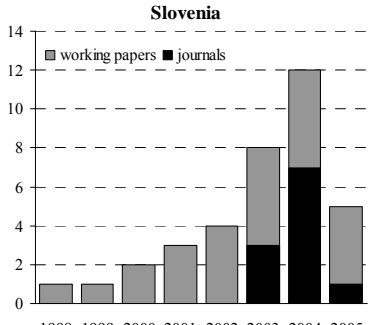

19981999200020012002200320042005

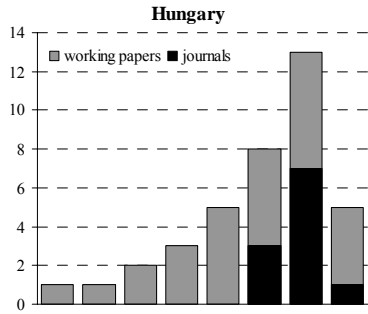

19981999200020012002200320042005

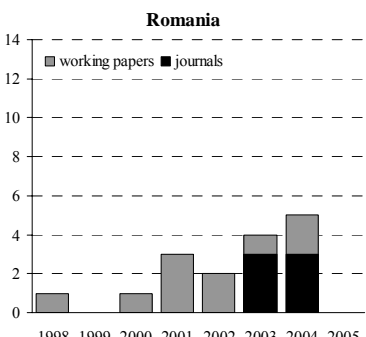

19981999200020012002200320042005 


\subsection{Meta-statistics}

The largest number of correlation estimates (58) are reported for the Czech Republic and Hungary, but there are sufficiently many estimates reported for all Central European countries and the Baltic States (see Table 1). By contrast, only 14 and 17 available estimates are reported for Bulgaria and Romania, respectively. It should be noted that we are able to compare estimates across studies directly. Whatever the exact methodology, all the studies arrive at a single statistic, i.e. the correlation coefficient. In some other meta-analyses the authors must classify or transform the reported estimates in some way.

On average, the highest average estimates of business cycle correlation with the euro area are reported for Hungary, followed by Slovenia and Poland. The studies report on average a negative correlation of business cycle only for Lithuania. For the entire data set, the mean is slightly higher than median, possibly implying some outliers are influential. The skewness statistic, which is positive for the average of all ten CEECs, indicates that the distribution of reported results is asymmetric with a long right tail (see Figure 2). Furthermore, the kurtosis statistic shows that the distribution of reported results is flat relative to a normal distribution. Nevertheless, the null of normal distribution of the results can be rejected only for Poland and Romania; we cannot reject the normality of the reported results when we pool the data for all countries. This can be also seen in the histograms of the reported results (Figure 2). In summary, it seems that there is no clear-cut consensus regarding the extent of business cycle correlation.

Table 2: Meta-statistics

\begin{tabular}{lrrrrrrrrrrr}
\hline & CE10 & CZ & HU & PL & SK & SI & EE & LV & LT & BG & RO \\
\hline Observ. & 463 & 58 & 57 & 58 & 54 & 54 & 53 & 51 & 47 & 17 & 14 \\
Mean & 0.153 & 0.166 & 0.359 & 0.249 & 0.014 & 0.257 & 0.141 & 0.104 & -0.069 & 0.075 & 0.069 \\
Median & 0.140 & 0.141 & 0.320 & 0.290 & 0.020 & 0.263 & 0.110 & 0.110 & -0.120 & 0.030 & -0.010 \\
Maximum & 0.980 & 0.840 & 0.930 & 0.880 & 0.900 & 0.980 & 0.980 & 0.960 & 0.920 & 0.480 & 0.860 \\
Minimum & -0.740 & -0.390 & -0.400 & -0.690 & -0.740 & -0.460 & -0.570 & -0.490 & -0.660 & -0.593 & -0.193 \\
Std. Dev. & 0.334 & 0.261 & 0.297 & 0.325 & 0.335 & 0.334 & 0.306 & 0.280 & 0.375 & 0.269 & 0.285 \\
Skewness & 0.013 & 0.361 & -0.141 & -0.780 & 0.202 & -0.224 & 0.354 & 0.372 & 0.737 & -0.595 & 1.737 \\
Kurtosis & 2.929 & 2.832 & 2.828 & 3.949 & 3.441 & 2.627 & 3.378 & 4.007 & 3.240 & 3.343 & 5.352 \\
Jarque-Bera & 0.112 & 1.327 & 0.258 & $8.056^{* *}$ & 0.807 & 0.767 & 1.425 & 3.329 & 4.367 & $1.08810 .272^{* *}$ \\
$t$-statistic & 9.879 & $4.846^{* * *}$ & $9.115^{* * *}$ & $5.831^{* * *}$ & 0.307 & $5.652^{* * *}$ & $3.347^{* * *}$ & $2.658^{* *}$ & -1.259 & 1.152 & 0.905 \\
\hline
\end{tabular}

Notes: $* / * * / * * *$ denote significance at the $10 \% / 5 \% / 1 \%$ level. 
Figure 2: Histograms of available correlation estimates

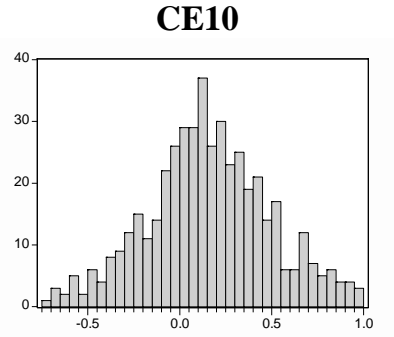

Hungary

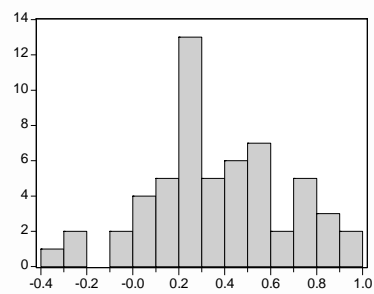

Bulgaria

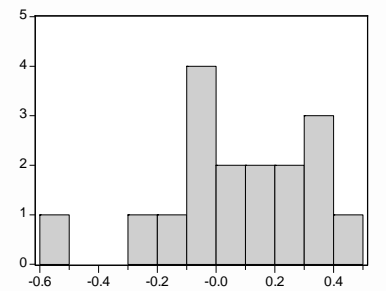

Latvia

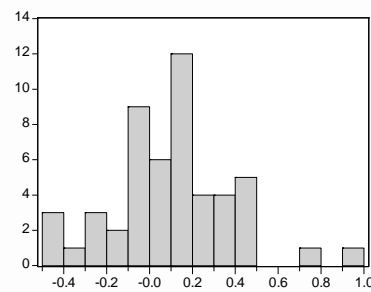

Czech Republic

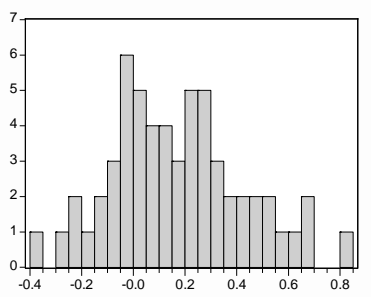

Lithuania

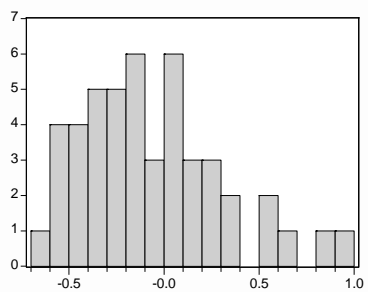

Estonia

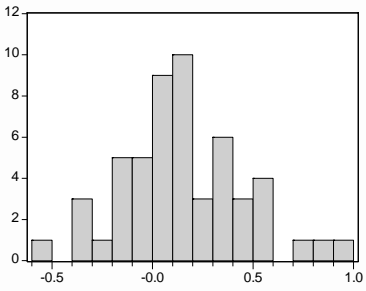

Poland

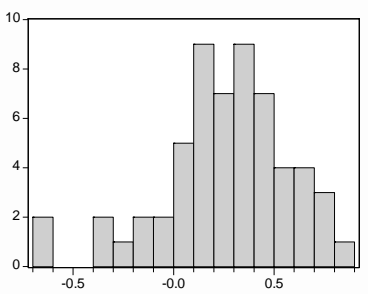

Slovenia

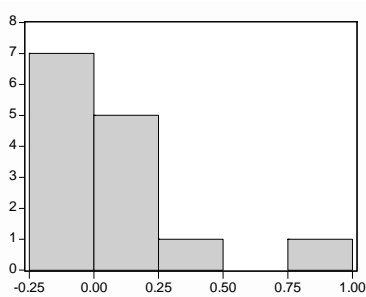

Slovakia

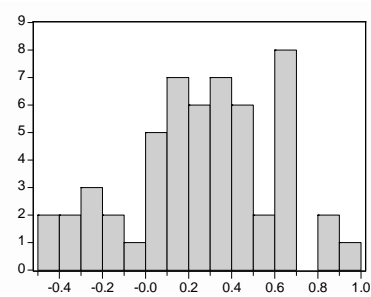

Somewhat surprisingly, the variance of reported results is quite similar between countries. Countries with relatively low average correlations (Bulgaria, Czech Republic, and Romania) also have relatively low standard deviations of reported results. A $t$-test rejects that the mean of reported results equals zero for six CEECs (Czech Republic, Hungary, Latvia, Poland, Slovenia, and Estonia).

Similar $t$-tests of equal means (reported in Table 3) between the CEECs reveal further insights. Results concerning Hungary are clearly different from other countries' results, with the possible exception of Poland. This result reinforces the view that Hungary's business cycle has the highest correlation with the euro area among the new EU member countries. On the other hand, business cycle correlations in Slovenia are not statistically different from Polish correlations (and the average correlations in both countries are almost the same). The Czech Republic, Estonia, and Latvia appear to form a group with reasonably similar correlation patterns. Slovakia and Lithuania, on the other hand, are quite different from the other countries (and from each other). Slovakia's correlation is positive, but small. Lithuania, as mentioned, is the only country in the sample with a negative average correlation. 
Table 3: Test of correlation equality between the CEECs

\begin{tabular}{l|rrrrrrr}
\hline & CZ & HU & PL & SK & SI & EE & LV \\
\hline HU & $0.0008^{* * *}$ & & & & & & \\
PL & $0.0247^{* *}$ & 0.1286 & & & & & \\
SK & $0.0415^{* *}$ & $0.0000^{* * *}$ & $0.0005^{* * *}$ & & & & \\
SI & $0.0577^{*}$ & $0.0955^{*}$ & 0.4023 & $0.0020^{* * *}$ & & & \\
EE & 0.3638 & $0.0008^{* * *}$ & $0.0184^{* *}$ & 0.1031 & $0.0413^{* *}$ & & \\
LV & 0.2925 & $0.0004^{* * *}$ & $0.0113^{* *}$ & 0.1339 & $0.0278^{* *}$ & 0.4308 & \\
LT & $0.0107^{* *}$ & $0.0000^{* * *}$ & $0.0002^{* * *}$ & 0.1929 & $0.0006^{* * *}$ & $0.0280^{* *}$ & $0.0370^{* *}$ \\
\hline
\end{tabular}

Notes: We report $p$-values of $t$-tests of equal means. */**/*** denote significance at the $10 \% / 5 \% / 1 \%$ level.

\subsection{Ranking analysis}

The relative ranking of business cycle correlation in the CEECs could shed additional light on the robustness of the estimated correlations, as the estimation methods usually differ substantially from one study to another. As the geographical focus of papers reviewed here varies quite a bit, we concentrate on studies that include all new EU member countries in Central and Eastern Europe (Czech Republic, Estonia, Hungary, Latvia, Lithuania, Poland, Slovakia, and Slovenia). All in all, our database contains 65 different estimates of business cycle synchronization (some papers reporting several estimates). Of these, 47 estimate correlations for all eight new EU members. Using all eight new member countries has become far more common in the last two years.

Figure 2 shows the average ranking of various countries in the studies, as well as the spreads given by plus/minus one standard deviation of the rankings. We can see at a glance that Hungary has the lowest ranking in the studies (i.e. highest correlation), followed by Poland and Slovenia. Average rankings of Estonia, Latvia and the Czech Republic are almost identical, while Slovakia and Lithuania trail behind the others. This gives a rough ordering among the new EU member countries when it comes to the correlation of business cycles. However, the standard deviations of the rankings are also fairly large.

Spearman's rank correlations ${ }^{5}$ for the 47 estimates under scrutiny reveal that rankings change from paper to paper, sometimes quite drastically. The average of all 1,081 rank correlations (given by $(47 * 47-47) / 2$ ), is 0.25 . Calculating the averages of rank

\footnotetext{
${ }^{5}$ Spearman's rank correlation $r$ is defined as $r=1-6 \sum\left[d^{2} / N\left(N^{2}-1\right)\right]$, where $d$ denotes the difference in the ranking of observations (in our case countries) and $N$ is the number of ranks (in our case eight).
} 
correlations for all individual papers, it turns out that six papers have negative average correlation with the other papers: Horvath (ranking based on demand shock, 2000) with rank correlation of -0.26 , Horvath and Rátfai (demand shock, 2004) -0.25, Korhonen (2003) -0.12, IMF (inflation, 2000) -0.07, European Forecasting Network (supply shock, 2003) -0.07, and Hagara and Fidrmuc (demand shock, 2004) -0.04. Approximately ten papers have average rank correlations between 0.4 and 0.5 ; the rest lie between zero and 0.4. In other words, most papers at in modest agreement with the remaining publications in the field with respect to the relative ranking of the new EU member countries.

\section{Figure 2: Average and spreads given by plus/minus one standard deviation of rankings}

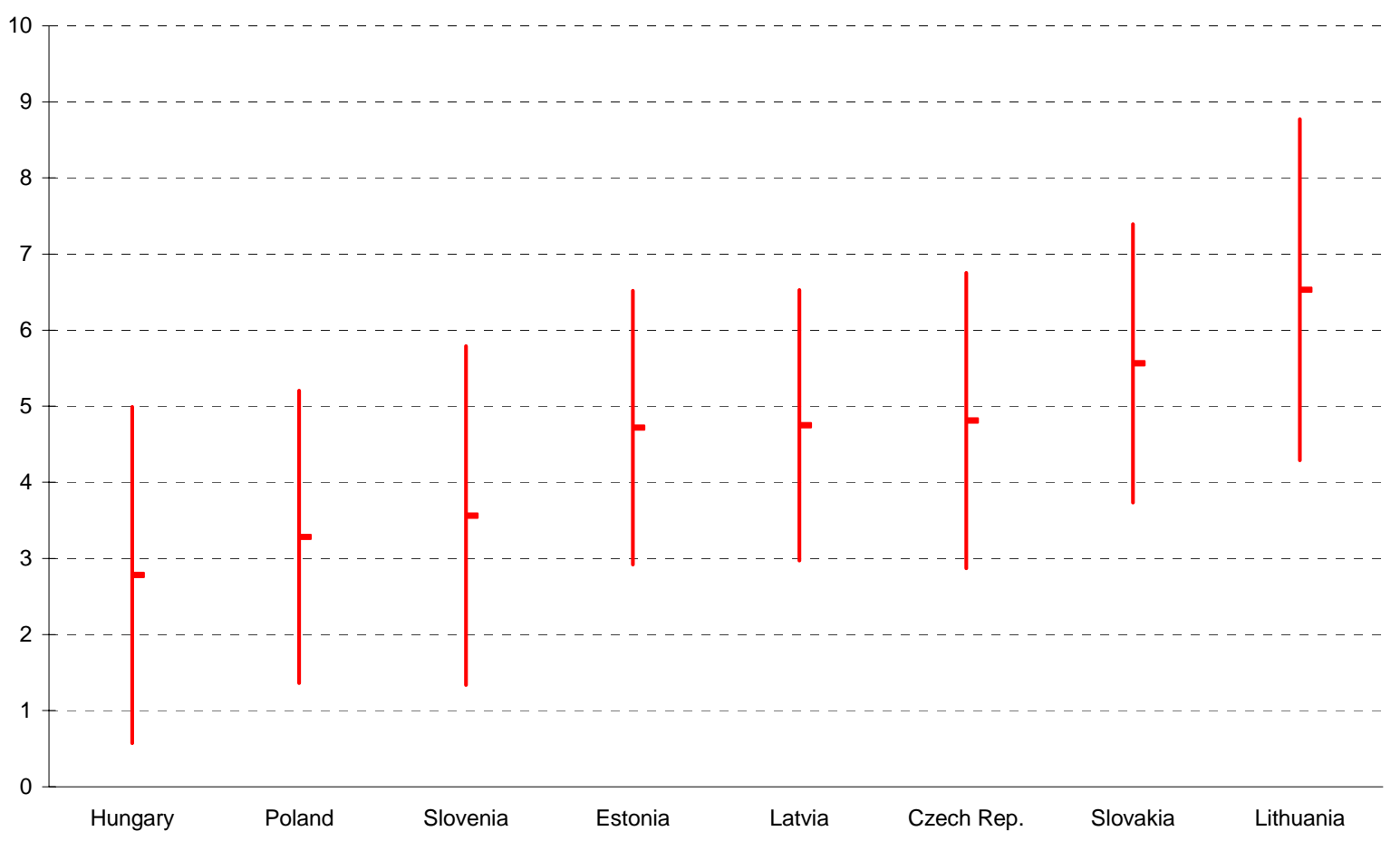

\subsection{Position of new member states within the EU}

In addition to the previous analyses, we study here how the CEECs perform in comparison with some peripheral current members of the euro area. Many studies include at least one of the peripheral euro area economies (e.g. Greece, Ireland or Portugal) in their data samples. It is thus natural to compare the estimated correlations in the CEECs with correlations of small current euro area members. Comparison with the correlation of their business cycle with the euro area cycle helps us to gauge how far the new EU member states have advanced in business cycle correlation. If business cycle correlation in a new EU member state is higher 
than in, say, Ireland and Portugal, we have greater confidence that the new EU country has progressed far enough in fulfilling this OCA criterion. Correspondingly, Figure 3 shows the share of studies where a CEEC had higher business cycle correlation with the euro area than Greece, Ireland or Portugal.

Most new member countries do very well indeed in this regard. Results are more or less in line with the relative rankings surveyed earlier. Hungary has higher business cycle correlation than the three peripheral euro area members in most cases. Poland and Slovenia are only slightly behind, although it should be noted that business cycle correlation in Ireland appears to be much higher than that of Greece of Portugal. Even a country such as Latvia, which ranked generally low in the relative ranking among the new member countries, has higher correlation than Greece in approximately half of the cases. These results would imply that even though the degree of correlation in the new member countries is far from perfect, they could still be expected to manage reasonably well within the monetary union (i.e. on par with Greece, Ireland or Portugal).

Figure 3: Share of publications reporting CEE business cycle correlation with the euro area above those of the benchmark countries

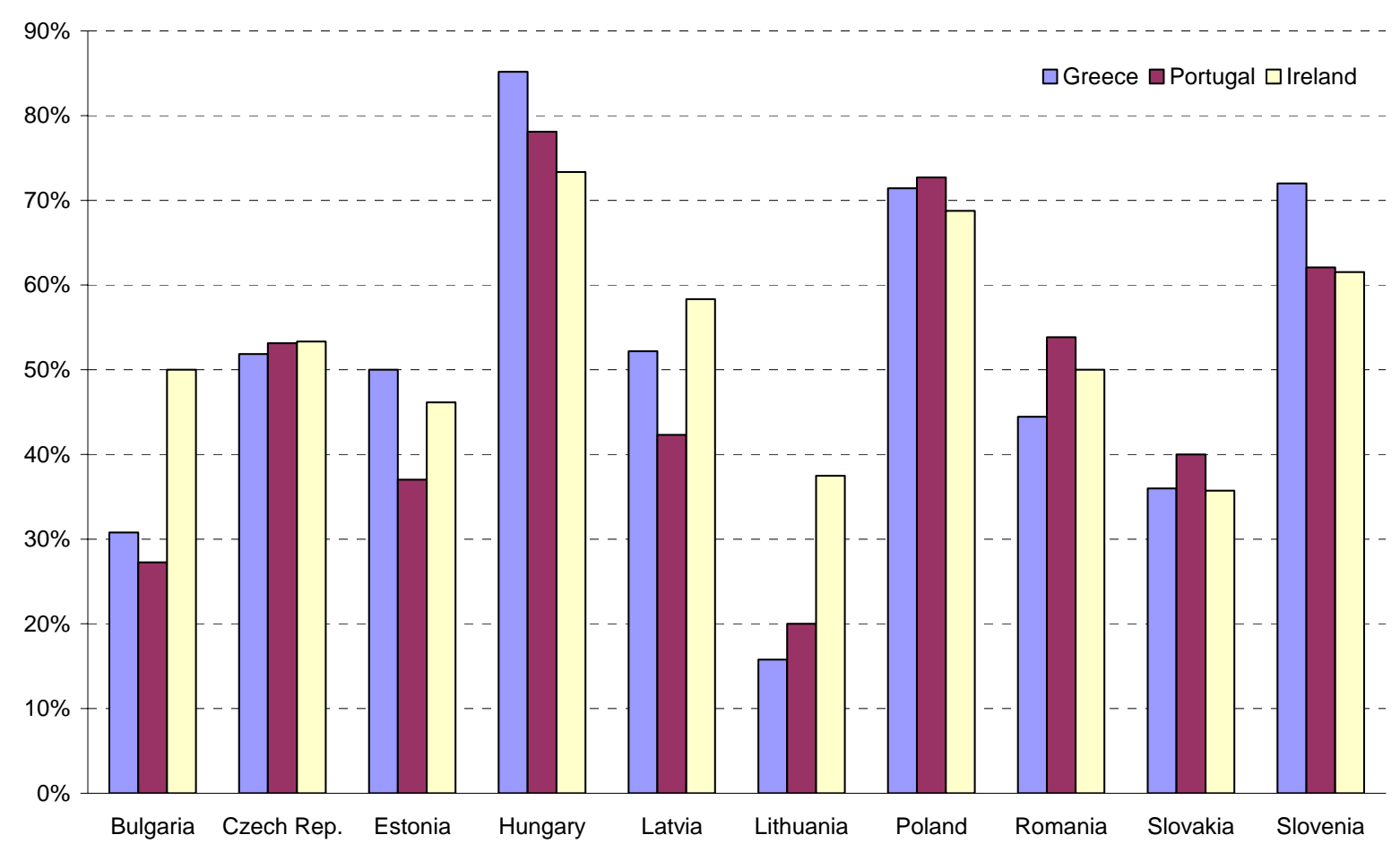




\subsection{Meta-regression analysis}

Meta statistics presented in Section 3.2 show that, on average, the available estimates of business cycle correlation provide a fairly consistent ranking of the CEECs. However, presented meta-statistics also prove a relatively high degree of variance among studies. It is generally argued that a substantial part of this variance can be attributed to the specifics of presented studies (especially data definition and selected time periods). Furthermore, there could be a publication bias of authors representing views accepted more or less in some countries or institutions.

Meta-regression analysis provides an appropriate tool to adjust for these effects. A meta-regression relates our summary statistics to a set of characteristics of reviewed studies. However, the correlation coefficient has some undesirable properties which may be important for regression results when it is defined between -1 and 1. Therefore, Lipsey and Wilson (2001) recommend Fisher's transformation which removes this restriction. ${ }^{6}$ Thus, the metaregression may be stated as

$$
\frac{1}{2} \log \left(\frac{1+\rho_{i j}}{1-\rho_{i j}}\right)=\widetilde{\rho}_{i}+\sum_{k=1}^{K} \beta_{i j k} D_{i j k}+\varepsilon_{i j},
$$

where $\rho_{i j}$ are correlation estimates reported by the source $j$ for country $i, D_{i j}$ are $K$ characteristics of reported summary statistics (some characteristics, e.g. sample periods, may be different between countries also according to the same source), and $\varepsilon$ is the error term with standard statistical properties.

This specification assumes that the characteristics of the reviewed studies have the same effects for all reported countries (i.e. there is no country specific bias of the individual studies). We are mainly interested in the country effect, $\widetilde{\rho}_{i}$. After the transformation back to standard correlation coefficients, this is our meta-estimate of the degree of business cycle synchronization with the euro area.

\footnotetext{
${ }^{6}$ For a correlation index sufficiently distant from the limit values, the Fisher's transformation is approximately equal to the original values. The index converges to $\infty$ and $-\infty$ as correlation approaches 1 and -1 , respectively. Although this may make the transformation sensitive to large outliers, our sensitivity analysis confirmed a high robustness of results (see Table 5).
} 
We start with average country estimates without any additional characteristics, ${ }^{7}$ which basically replicate the computation of meta-statistics above (note that we use Fisher's transformation of the correlation coefficient here). This confirms the significance of business cycle correlation with the euro area in the Czech Republic, Estonia, Hungary, Latvia, Poland, and Slovenia (see Table 4), although the size effects are again different. We next add several sets of indicators characterizing reviewed estimates of business correlation, which are reported in separate columns in Table 4. Quarterly data (QUARTER) lead to lower reported correlation of business cycles between the countries than monthly or annual data, while the use of industrial production has no significant effect. The number of observations (OBS) has a negative, but insignificant, effect. ${ }^{8}$ The application of time series models (TSERIES), statistical filters (HP) and SVARs (SVAR) has negative effects comparative to simple correlation coefficients of growth rates. It may be that simple growth rate correlations do not adequately reflect the underlying business cycle correlation.

Synchronization of business cycle as measured by the supply (SUPPLY) and demand shocks (DEMAND) goes in the same direction (again negative, as implied by the coefficient on the SVAR dummy variable) by approximately the same amount, while correlation of inflation (CPI) provides greater business cycle correlation than summary statistics based on GDP or industrial production (Q).

We also look for possible publication bias in the field. We find a negative trend in the reported correlation coefficients (YEAR, measured by demeaned year of publication). This pattern is confirmed when we include year dummies. Year of publication seems to work better than comparable indicators for the applied time period (starting and final year of the sample in surveyed publications). In contrast, a dummy for journal publications (JP) is not significant. We also find that authors affiliated at the central banks in the CEECs (ACEE) tend to be more conservative than authors working for the eurosystem (AEMU) or in academic institutions.

\footnotetext{
${ }^{7}$ This approach reflects that some explanatory variables may be correlated. We try to reflect this feature of our data set in the final specification.

${ }^{8}$ We get the same results if we take the lengths of time period in months.
} 
Table 4: Meta-regressions of business cycle correlations between the euro area and the CEECs

\begin{tabular}{|c|c|c|c|c|c|c|c|c|}
\hline & $\begin{array}{c}\text { Basic } \\
\text { estimation }\end{array}$ & $\begin{array}{c}\text { Data } \\
\text { frequency }\end{array}$ & $\begin{array}{l}\text { Method of } \\
\text { estimation }\end{array}$ & $\begin{array}{c}\text { Applied } \\
\text { variables } \\
\end{array}$ & $\begin{array}{c}\text { Publica- } \\
\text { tions' bias }\end{array}$ & $\begin{array}{c}\text { Authors' } \\
\text { bias }\end{array}$ & $\begin{array}{c}\text { All } \\
\text { variables }\end{array}$ & $\begin{array}{l}\text { Preferred } \\
\text { estimation }\end{array}$ \\
\hline \multirow[t]{2}{*}{$\mathrm{CZ}$} & 0.187 & 0.637 & 0.411 & 0.219 & 0.191 & 0.273 & 0.521 & 0.303 \\
\hline & $(4.651)$ & (4.942) & $(6.033)$ & $(4.500)$ & $(4.780)$ & (5.653) & $(5.030)$ & $(6.387)$ \\
\hline \multirow[t]{2}{*}{$\mathrm{HU}$} & 0.437 & 0.887 & 0.661 & 0.468 & 0.441 & 0.521 & 0.762 & 0.555 \\
\hline & $(7.846)$ & $(6.701)$ & (8.891) & $(8.036)$ & $(7.261)$ & (8.661) & $(6.866)$ & (8.671) \\
\hline \multirow[t]{2}{*}{ PL } & 0.281 & 0.730 & 0.501 & 0.309 & 0.283 & 0.367 & 0.604 & 0.395 \\
\hline & (5.385) & (5.659) & (6.970) & (5.400) & (5.067) & (6.098) & (5.663) & $(6.645)$ \\
\hline \multirow[t]{2}{*}{ SK } & 0.024 & 0.482 & 0.254 & 0.057 & 0.032 & 0.112 & 0.358 & 0.150 \\
\hline & $(0.436)$ & (3.599) & (3.085) & $(0.874)$ & $(0.557)$ & (1.824) & $(3.272)$ & $(2.396)$ \\
\hline \multirow[t]{2}{*}{ SI } & 0.318 & 0.766 & 0.539 & 0.346 & 0.323 & 0.398 & 0.642 & 0.435 \\
\hline & (4.984) & (5.314) & (6.479) & $(6.027)$ & (4.974) & $(5.460)$ & (5.524) & $(6.882)$ \\
\hline \multirow[t]{2}{*}{ EE } & 0.182 & 0.626 & 0.400 & 0.212 & 0.195 & 0.268 & 0.504 & 0.304 \\
\hline & (2.997) & $(4.445)$ & (4.641) & (3.464) & (3.112) & (3.848) & (4.414) & $(4.844)$ \\
\hline \multirow[t]{2}{*}{ LV } & 0.131 & 0.579 & 0.357 & 0.160 & 0.145 & 0.216 & 0.458 & 0.259 \\
\hline & $(2.452)$ & $(4.276)$ & $(4.625)$ & (2.965) & (2.622) & (3.431) & (4.240) & $(4.844)$ \\
\hline \multirow[t]{2}{*}{ LT } & -0.053 & 0.387 & 0.166 & -0.033 & -0.034 & 0.039 & 0.265 & 0.071 \\
\hline & $(0.751)$ & (2.710) & $(1.870)$ & $(0.480)$ & $(-0.490)$ & $(0.526)$ & $(2.261)$ & $(0.976)$ \\
\hline \multirow[t]{2}{*}{ BG } & 0.077 & 0.509 & 0.298 & 0.095 & 0.054 & 0.144 & 0.353 & 0.167 \\
\hline & (1.100) & (3.725) & (3.777) & (1.076) & $(0.710)$ & (1.797) & (2.719) & (1.919) \\
\hline \multirow[t]{2}{*}{ RO } & 0.102 & 0.497 & 0.275 & 0.048 & -0.004 & 0.155 & 0.303 & 0.133 \\
\hline & (1.016) & $(3.262)$ & (2.425) & $(0.487)$ & $(-0.053)$ & (1.457) & (2.291) & $(1.565)$ \\
\hline \multirow[t]{2}{*}{ MONTH } & & -0.080 & & & & & 0.129 & \\
\hline & & $(0.481)$ & & & & & $(0.725)$ & \\
\hline \multirow[t]{2}{*}{ QUARTER } & & -0.434 & & & & & -0.145 & \\
\hline & & $(3.460)$ & & & & & $(-1.195)$ & \\
\hline \multirow[t]{2}{*}{ OBS } & & -0.003 & & & & & -0.005 & \\
\hline & & (1.915) & & & & & $(-2.644)$ & \\
\hline \multirow[t]{2}{*}{ TSERIES } & & & -0.194 & & & & -0.031 & \\
\hline & & & (2.014) & & & & $(-0.349)$ & \\
\hline \multirow[t]{2}{*}{ SVAR } & & & -0.319 & & & & -0.025 & \\
\hline & & & (5.101) & & & & $(-0.331)$ & \\
\hline \multirow[t]{2}{*}{ HP } & & & -0.189 & & & & -0.062 & -0.120 \\
\hline & & & (2.663) & & & & $(-0.831)$ & $(2.204)$ \\
\hline \multirow[t]{2}{*}{ Q } & & & & 0.120 & & & 0.224 & \\
\hline & & & & (1.894) & & & (2.943) & \\
\hline \multirow[t]{2}{*}{ SUPPLY } & & & & -0.148 & & & -0.132 & -0.233 \\
\hline & & & & (3.719) & & & $(-2.475)$ & $(5.349)$ \\
\hline \multirow[t]{2}{*}{ DEMAND } & & & & -0.127 & & & -0.116 & -0.219 \\
\hline & & & & (2.749) & & & $(-2.202)$ & $(4.422)$ \\
\hline CPI & & & & 0.435 & & & 0.330 & 0.367 \\
\hline & & & & (3.004) & & & $(2.725)$ & $(2.940)$ \\
\hline YEAR & & & & & -0.041 & & -0.036 & -0.042 \\
\hline & & & & & $(-2.707)$ & & $(-2.921)$ & $(3.590)$ \\
\hline JP & & & & & 0.002 & & 0.001 & \\
\hline & & & & & $(0.043)$ & & $(0.022)$ & \\
\hline ACEE & & & & & & -0.209 & -0.059 & \\
\hline & & & & & & (5.069) & $(-1.371)$ & \\
\hline AEMU & & & & & & -0.073 & 0.008 & \\
\hline & & & & & & $(1.768)$ & $(0.156)$ & \\
\hline Observ. & 453 & 453 & 453 & 453 & 453 & 453 & 453 & 453 \\
\hline Adjusted $\mathrm{R}^{2}$ & 0.095 & 0.201 & 0.174 & 0.209 & 0.119 & 0.132 & 0.273 & 0.236 \\
\hline
\end{tabular}

Note: $t$-statistics are in parentheses. 
Table 5: Sensitivity Analysis

\begin{tabular}{|c|c|c|c|c|c|c|c|c|}
\hline & $\begin{array}{l}\text { Preferred } \\
\text { estimation }\end{array}$ & $\begin{array}{c}\text { Data } \\
\text { from‘95 }\end{array}$ & $\begin{array}{c}\text { Published } \\
\text { 2002-05 } \\
\end{array}$ & $\begin{array}{c}\text { Only } \\
\text { SVAR }\end{array}$ & $\begin{array}{c}\text { Only quar- } \\
\text { terly data }\end{array}$ & $\begin{array}{l}\text { Only } \\
\text { CE5 }\end{array}$ & $\begin{array}{c}\text { No } \\
\text { outliers }\end{array}$ & $\begin{array}{c}\text { CPI } \\
\text { excluded }\end{array}$ \\
\hline \multirow[t]{2}{*}{$\mathrm{CZ}$} & 0.303 & 0.202 & 0.238 & 0.298 & 0.288 & 0.284 & 0.305 & 0.285 \\
\hline & $(6.387)$ & $(2.825)$ & $(5.037)$ & $(5.127)$ & (5.419) & $(5.368)$ & $(6.767)$ & (5.994) \\
\hline \multirow[t]{2}{*}{$\mathrm{HU}$} & 0.555 & 0.461 & 0.537 & 0.410 & 0.547 & 0.536 & 0.507 & 0.551 \\
\hline & $(8.671)$ & $(5.201)$ & $(8.167)$ & $(5.487)$ & (7.353) & $(7.985)$ & $(9.926)$ & $(8.737)$ \\
\hline \multirow[t]{2}{*}{ PL } & 0.395 & 0.363 & 0.338 & 0.332 & 0.347 & 0.377 & 0.430 & 0.366 \\
\hline & $(6.645)$ & $(4.573)$ & $(5.373)$ & $(4.848)$ & (4.769) & $(5.871)$ & $(9.005)$ & (6.148) \\
\hline \multirow[t]{2}{*}{ SK } & 0.150 & -0.015 & 0.062 & 0.138 & 0.088 & 0.130 & 0.127 & 0.118 \\
\hline & $(2.396)$ & $(-0.148)$ & (1.015) & $(2.649)$ & $(1.271)$ & (1.847) & $(2.492)$ & (1.867) \\
\hline \multirow[t]{2}{*}{ SI } & 0.435 & 0.305 & 0.358 & 0.226 & 0.346 & 0.415 & 0.408 & 0.389 \\
\hline & $(6.882)$ & $(3.853)$ & $(6.225)$ & $(3.402)$ & $(5.352)$ & $(6.035)$ & $(8.351)$ & (6.682) \\
\hline \multirow[t]{2}{*}{$\mathrm{EE}$} & 0.304 & 0.167 & 0.212 & 0.238 & 0.269 & & 0.245 & 0.254 \\
\hline & $(4.844)$ & $(2.236)$ & $(3.633)$ & (3.996) & $(5.626)$ & & $(5.635)$ & $(4.422)$ \\
\hline \multirow[t]{2}{*}{ LV } & 0.259 & 0.142 & 0.163 & 0.160 & 0.209 & & 0.222 & 0.204 \\
\hline & $(4.844)$ & $(2.317)$ & $(3.550)$ & $(2.922)$ & $(4.376)$ & & (4.951) & (4.150) \\
\hline \multirow[t]{2}{*}{$\mathrm{LT}$} & 0.071 & -0.081 & -0.032 & 0.010 & 0.020 & & 0.024 & 0.016 \\
\hline & $(0.976)$ & $(-0.767)$ & $(-0.440)$ & $(0.164)$ & $(0.288)$ & & $(0.424)$ & $(0.214)$ \\
\hline \multirow[t]{2}{*}{$\mathrm{BG}$} & 0.167 & 0.081 & 0.168 & 0.133 & 0.205 & & 0.225 & 0.227 \\
\hline & (1.919) & $(0.836)$ & $(3.033)$ & (1.319) & $(2.328)$ & & (3.846) & (3.138) \\
\hline \multirow[t]{2}{*}{$\mathrm{RO}$} & 0.133 & -0.068 & 0.046 & 0.209 & 0.155 & & 0.152 & 0.103 \\
\hline & $(1.565)$ & $(-0.676)$ & $(0.841)$ & $(3.012)$ & $(2.252)$ & & $(1.747)$ & (1.623) \\
\hline \multirow[t]{2}{*}{ HP } & -0.120 & -0.299 & -0.057 & & -0.206 & -0.019 & -0.101 & -0.047 \\
\hline & (2.204) & $(-2.852)$ & $(-1.074)$ & & $(-2.767)$ & $(-0.261)$ & $(-2.354)$ & $(-0.871)$ \\
\hline \multirow[t]{2}{*}{ SUPPLY } & -0.233 & -0.182 & -0.150 & -0.165 & -0.206 & -0.213 & -0.195 & -0.205 \\
\hline & (5.349) & $(-3.223)$ & $(-3.468)$ & $(-3.574)$ & $(-4.262)$ & $(-3.670)$ & $(-5.370)$ & $(-4.767)$ \\
\hline \multirow[t]{2}{*}{ DEMAND } & -0.219 & -0.153 & -0.149 & -0.137 & -0.217 & -0.220 & -0.198 & -0.187 \\
\hline & (4.422) & $(-2.369)$ & $(-2.913)$ & $(-2.645)$ & $(-4.103)$ & $(-3.519)$ & $(-4.661)$ & $(-3.770)$ \\
\hline \multirow[t]{2}{*}{ CPI } & 0.367 & 0.339 & 0.022 & & -0.057 & 0.267 & 0.137 & \\
\hline & $(2.940)$ & $(2.481)$ & $(0.389)$ & & $(-0.745)$ & (1.634) & $(1.726)$ & \\
\hline \multirow[t]{2}{*}{ YEAR } & -0.042 & 0.143 & & 0.015 & 0.011 & -0.027 & -0.035 & -0.020 \\
\hline & $(3.590)$ & $(2.911)$ & & (1.101) & $(0.846)$ & $(-1.836)$ & $(-3.594)$ & $(-1.837)$ \\
\hline Observ. & 453 & 235 & 399 & 250 & 340 & 281 & 438 & 435 \\
\hline Adjusted $\mathrm{R}^{2}$ & 0.236 & 0.222 & 0.197 & 0.130 & 0.214 & 0.188 & 0.270 & 0.195 \\
\hline
\end{tabular}

Note: CE5 - Czech Republic, Hungary, Poland, Slovakia, and Slovenia. $t$-statistics are in parentheses.

In the next step, we include all characteristics into a single equation. This shows that characteristics describing the variables have the most robust influence on results. Conversely, we see that variables pointing at possible publication bias are no longer significant. If we drop insignificant variables, we get our preferred meta-regression which involves a dummy for statistical filters, supply and demand shocks, a dummy for inflation used as variable measuring the business cycles, and the year of publication. In this specification (as well as in the majority of specifications including only a subset of characteristics), we find positive and significant correlation of business cycles with the euro area for all CEECs, which range between 0.1 for Lithuania and 0.5 for Hungary. Consequently, the differences between the CEECs appear to be even larger than in the original studies. Moreover, the ranking of CEECs 
confirms the results of the previous section, although recent analysis shows a slightly better ranking for the Czech Republic.

We now analyze the robustness of the preferred estimation in Table 5, noting that several authors claim that earlier studies are less reliable because of the shorter period and transitional recession (see for example Campos and Coricelli, 2002; Fidrmuc and Korhonen, 2003, 2004; and Babetskii et al., 2002). First, we exclude all studies utilizing data before 1995 as they are likely to be biased by the transitional recession. Second, we consider only results published after 2002, because longer and reliable time series have been made available only in this period. Finally, we include only studies based on structural VARs, because this methodology seems to dominate the current discussion. In general, these reformulations do not change the results with respect to our explanatory variables.

The ranking of the countries remains nearly unchanged. However, we can see that Poland and the Czech Republic show now a slightly higher degree of business cycle correlation with the euro area, while Slovenian correlation becomes somewhat smaller.

We next restrict our data set to publications using quarterly data or five Central European countries (CE5) with the highest number of observations. Finally, we control for outliers identified as observations, where residuals normalized by the standard error of regression are larger in absolute value than 1.95 . Thus, we identify 25 outliers (approximately $5 \%$ of observations). These are spread evenly across countries. Table 5 shows that all explanatory variables of the preferred regression (with a possible exception for correlation of inflation ${ }^{9}$ ) keep their signs and remain significant. To further check the importance of inflation correlation for the overall results, we drop observations based on correlation of inflation rates from the final regression. This final sensitivity check confirms the previous findings. Moreover, the ranking of the countries remains stable during sensitivity tests. This robustness analysis allows us to conclude that our results are not overly sensitive to the exact specification used. Therefore, we can safely proceed to our conclusions.

\footnotetext{
${ }^{9}$ Please keep in mind that only one publication uses quarterly data and correlation of inflation rates at the same time. Eight observations on inflation correlation (out of 28 observations) are identified as outliers. The list of all outliers is available from the authors upon request.
} 


\section{Conclusions}

Our literature survey documented large differences between publications analyzing the fulfillment of the OCA criteria by the CEECs. Nevertheless, the presented meta-analysis confirmed that the economic cycles in several CEECs are highly correlated with the euro area cycle. Thus, despite the apparent lack of consensus on the topic, careful examination of all the studies allows us to conclude that we actually know quite a bit about business cycle correlation between the euro area and the new EU members.

Many new EU member states have achieved a relatively high degree of business cycle correlation with the euro area. This seems to be especially true for Hungary, Poland and Slovenia. Although the Baltic countries were not always included in the aforementioned studies, there is also evidence that Estonia has achieved a certain degree of convergence with the euro area cycle. Indeed, correlation of business cycles in several CEECs appears to match or exceed the convergence of several of the smaller, peripheral monetary union members.

Of course, we admit that the new EU countries may want to join the EU for reasons unrelated to OCA considerations. For example, all Baltic countries already fix their currencies to the euro within very narrow bands (actually zero-bands), even though correlation of their business cycles with the euro area cycle is not among the highest within the group of new EU countries. For a small country with illiquid financial markets, a floating exchange rate might well be a source of large, destabilizing shocks, which makes a fixed exchange rate and ultimately monetary union quite desirable (Coricelli et al., 2006). Furthermore, joining the euro area is also very much a political decision, related to the general progress of integration within the EU. Nevertheless, even if the ultimate decision of joining the monetary union is political, the degree of business cycle correlation will have an effect on the cost-benefit calculation.

In our meta-analysis of the studies dealing with business cycle correlation, we were able to confirm relatively high correlations for many new EU member countries. In addition, we found that characteristics of individual studies have had a clear impact on the estimated correlations. For example, studies using quarterly data report on average lower correlations than those utilizing monthly data. Simple growth rate correlations were higher than correlations calculated from models with slightly more economic structure behind them. For these reasons, some economists tend to trust the more conservative estimates. In turn, we do not observe any effect from the country of residence of the researcher. As a non-momentous aside, we note central bankers tend be more conservative in their estimates. 
Our analysis implies that the business cycle correlation of most new EU member countries is sufficiently high as not to hinder membership in the monetary union. Indeed, several current members of the euro area appear to have lower business cycle correlations than new EU members. Moreover, business cycle correlation is only one criterion of successful participation in a monetary union. Economic policies also need to be congruent with the demands of the monetary union. 


\section{References}

Artis, Michael, 2003a. Is there a European business cycle? Working Paper No. 1053. CESifo, Munich.

Artis, Michael, 2003b. Analysis of European and United Kingdom Business Cycles and Shocks. Available at www.hm-treasury.gov.uk, HM Treasury.

Artis, Michael, Marcellino, Massimiliano, Proietti, Tommaso, 2004. Characterising the business cycles for accession countries. Discussion Paper No. 4457. CEPR, London.

Artis, Michael, Zhang, Wenda, 1997. International business cycles and the ERM: Is there a European business cycle? International Journal of Finance and Economics 2, 1099-1158.

Babebtskii, Ian, 2004. EU enlargement and endogeneity of some OCA criteria: Evidence from the CEECs. Czech National Bank Working Paper No. 2, Prague.

Babetskii, Ian, Boone, Laurence, Maurel, Mathilde, 2002. Exchange rate regimes and supply shocks asymmetry: The case of the accession countries. Discussion Paper No. 3408. CEPR, London.

Babetskii, Ian, Boone, Laurence, Maurel, Mathilde, 2004. Exchange rate regimes and shocks asymmetry: The case of the accession countries. Journal of Comparative Economics 32, 212-229.

Backé, Peter, Fidrmuc, Jarko, Reininger, Thomas, Schardax, Franz, 2003. Price dynamics in Central and Eastern European EU accession countries. Emerging Markets Finance and Trade 39, 42-78.

Backé, Peter, Thimann, Christian, Arratibel, Olga, Calvo-Gonzalez, Oscar, Mehl, Arnaud, Nerlich, Carolin, 2004. The acceding countries' strategies towards ERM II and the adoption of the euro: An analytical review. ECB Occasional Paper No.10. Frankfurt am Main.

Barrell, Ray, Holland, Dawn, 2004. Modelling the accession countries: An analysis of symmetric and asymmetric structural shocks and the spillover effects in relation to the EU. CEPR-EABCN Conference on Business Cycle and Acceding Countries. Vienna.

Bayoumi, Tamin, Eichengreen, Barry, 1993. Shocking aspects of European monetary integration. In: Torres, Francisco, Giavazzi, Francesco (Eds.), Growth and Adjustment in the European Monetary Union, Cambridge University Press, Oxford, pp. 193-230.

Berger, Helge, de Haan, Jakob, Inklaar, Robert, 2004. Restructuring the ECB. In: Berger, Helge, Moutos, Thomas (Eds.), Managing European Union Enlargement, MIT Press, Cambridge, MA, pp. 29-72.

Blanchard, Olivier J., Quah, Danny, 1989. The dynamic effects of aggregate demand and supply disturbances. American Economic Review 79, 655-673.

Błaszkiewicz, Monika, Wozniak, Przemyslaw, 2003. Do candidate countries fit the optimum-currency-area criteria? Studies \& Analysis No. 267. Center for Social and Economic Research, Warsaw.

Boone, Laurence, Maurel, Mathilde, 1998. Economic convergence of the CEECs with the EU. Discussion Paper No. 2018. CEPR, London.

Boone, Laurence, Maurel, Mathilde, 1999. An optimal currency area perspective of the EU enlargement to the CEECs. Discussion Paper No. 2119. CEPR, London.

Boreiko, Dimitri, 2002. EMU and accession countries: Fuzzy cluster analysis of membership. Working Paper No. 71. Oesterreichische Nationalbank, Vienna.

Boreiko, Dimitri, 2003. EMU and accession countries: Fuzzy cluster analysis of membership. International Journal of Finance \& Economics 8, 309-325. 
Borghijs, Alain, Kuijs, Louis, Exchange rates in Central Europe: A blessing or a curse? Working Paper No. 04/2, International Monetary Fund, Washington D.C.

Borowski, Jakub, 2001. Podatność Polski na szoki asymetryczne a proces akcesji do Unii Gospodarczej i Walutowej. Bank i Kredyt 11-12, 10-21.

Buiter, Willem H., Grafe, Clemens, 2002. Anchor, float or abandon ship: Exchange rate regimes for accession countries. Discussion Paper No. 3184. CEPR, London.

Campos, Nauro F., Coricelli, Fabrizio, 2002. Growth in transition: What we know, what we don't, and what we should. Journal of Economic Literature XL, 793-836.

Clarida, Richard, Galí, Jordi, 1994. Sources of real exchange rate fluctuations: How important are nominal shocks. Working Paper No. 4658. NBER, Cambridge.

Csajbók, Attila, Csermely, Ágnes, 2002. Adopting the euro in Hungary: Expected costs, benefits and timing. Occasional Paper No. 24. Magyar Nemzeti Bank, Budapest.

Coricelli, Fabio, Jazbec, Boštjan, Masten, Igor, 2006. Exchange rate pass-through in candidate countries. Journal of Banking and Finance, forthcoming.

De Grauwe, Paul, Costa Storti, Claudia, Effects of monetary policy: A meta-analysis. Working Paper No. 1224. CESifo Munich.

Darvas, Zsolt, Szapáry, György, 2005. Business cycle synchronization in the enlarged EU: Comovements in the new and old members. Discussion Paper No. 5179. CEPR, London.

Darvas, Zsolt, Vadas, Gábor, 2005. A new method for combining detrending techniques with application to business cycle synchronization of the new EU members. Working Paper No. 5. Magyar Nemzeti Bank, Budapest.

Demyanyk, Yuliya, Volosovych, Vadym, 2005. Asymmetry of output shocks in the European Union: The difference between acceding and current members. Discussion Paper No. 4847. CEPR, London.

Eickmeier, Sandra, Breitung, Jörg, 2005. How synchronized are Central and East European economies with the euro area? Evidence from a structural factor model. Discussion Paper No. 20. Deutsche Bundesbank, Frankfurt am Main.

Égert, Balázs and László Halpern, 2006. Equilibrium exchange rates in Central and Eastern Europe: A metaregression analysis. Journal of Banking and Finance, forthcoming.

European Forecasting Network, 2003. EFN Report on the Euro Area Outlook. European Forecasting Network, Bocconi.

Fidrmuc, Jarko, 2001. The endogeneity of the optimum currency area criteria, intraindustry trade, and EMU enlargement. Discussion Paper No. 106/2001. Centre for Transition Economics, Katholieke Universiteit, Leuven.

Fidrmuc, Jarko, 2004. The endogeneity of the optimum currency area criteria, intra-industry trade, and EMU enlargement. Contemporary Economic Policy 22, 1-12.

Fidrmuc, Jarko, Hagara, Eduard, 2004. Podobnost' ponukových a dopytových šokov v EÚ a v pristupujúcich krajinách, Implikácie pre Českú republiku a Slovensko. Politická ekonomie 52, 171-182.

Fidrmuc, Jarko, Korhonen, Iikka, 2001. Similarity of supply and demand shocks between the euro area and the CEECs. BOFIT Discussion Paper No. 14. Bank of Finland, Institute for Economies in Transition, Helsinki.

Fidrmuc, Jarko, Korhonen, Iikka, 2003. Similarity of supply and demand shocks between the euro area and the CEECs. Economic Systems 27, 313-334. 
Fidrmuc, Jarko, Korhonen, Iikka, 2004. The euro goes East: Implications of the 2000-2002 economic slowdown for synchronization of business cycles between the euro area and CEECs. Comparative Economic Studies $46,45-62$.

Frankel, Jeffrey A., Rose, Andrew K., 1998. The endogeneity of the optimum currency area criteria. Economic Journal 108, 1009-1025.

Frenkel, Michael, Nickel, Christiane, 2002. How symmetric are the shocks and the shock adjustment dynamics between the euro area and Central and Eastern European countries? Working Paper No. 02/222, International Monetary Fund, Washington D.C.

Frenkel, Michael, Nickel, Christiane, 2005. How symmetric are the shocks and the shock adjustment dynamics between the euro area and Central and Eastern European Countries? Journal of Common Market Studies 43, 53-74.

Frenkel, Michael, Nickel, Christiane, Schmidt, Günter, 1999. Some shocking aspects of EMU enlargement, Research Note No. 99-4, Deutsche Bank, Frankfurt am Main.

Horníková, Martina, 2003. Optimum Currency Areas and Shock Asymmetry: A Comparison of Europe and the Czech Republic. Mimeo, Central European University, Budapest.

Horvath, Julius, 2000. Supply and demand shocks in Europe: Large-4 EU members, Visegrad-5 and Baltic-3 countries. Mimeo, Central European University, Budapest.

Horvath, Julius, Rátfai, Attila, 2004. Supply and demand shocks in accession countries to the European Monetary Union. Journal of Comparative Economics 32, 202-211.

International Monetary Fund, 2000. Chapter IV: Accession of transition economies to the European Union: Prospects and pressures. In: International Monetary Fund, World Economic Outlook—Prospects and Policy Issues. October 2000, International Monetary Fund, Washington, pp. 138-174.

Kalemli-Ozcan, Sebnem, Sørensen, Bent E., Yosha, Oved, 2001. Economic integration, industrial specialization, and the asymmetry of macroeconomic fluctuations. Journal of International Economics 55, 107-137.

Karmann, Alexander, Weimann, Marco, 2004. A closer shock convergence under EMU? Results of a VAR analysis, International Review of Economics and Business (RISEC), 51, 65-77.

Knell, Markus, Stix, Helmut, 2005. The income elasticity of money demand: A meta analysis of empirical results, Journal of Economic Surveys 19, 513-533.

Kočenda, Evžen, 2001. Macroeconomic convergence in transition economies. Journal of Comparative Economics 29, 1-23.

Korhonen, Iikka, 2001. Some empirical tests on the integration of economic activity between the euro area and the accession countries. Discussion Paper No. 9, Bank of Finland, Institute for Economies in Transition, Helsinki.

Korhonen, Iikka, 2003. Some empirical tests on the integration of economic activity between the euro area and the accession countries: A note. Economics of Transition 11, 1-20.

Kutan, Ali M., Yigit, Taner M., 2004. Nominal and real stochastic convergence of transition economies. Journal of Comparative Economics 32, 23-36.

Lättemäe, Raoul, 2003. EMU Accession issues in Baltic countries. Working Paper No. wp17a. Free University Berlin, Jean Monnet Centre of Excellence, Berlin.

Lipsey, Mark W., Wilson, David B., 2001. Practical Meta Analysis. Applied Social Research Methods Series, Vol. 49, SAGE Publications, London. 
Luikmel, Peeter, Randveer, Martti, 2003. The Synchronisation of the Estonian Business Cycle with its Main Trading Partners in Business Cycles - Country Experiences, ICFAI University Press, Hyderabad.

Maurel, Mathilde, 2002. On the way of EMU enlargement towards CEECs: What is the appropriate exchange rate regime? Discussion Paper No. 3409. CEPR, London.

Mundell, Robert A., 1961. A theory of optimum currency area. American Economic Review 51, 657-665.

Mundell, Robert A., 1973. Uncommon arguments for common currencies. In: Johnson, Harry G., Swoboda, Alexander K. (Eds.), The Economics of Common Currencies. London: Allen and Unwin, pp. 114-132.

Ramos, Raúl, Suriñach, Jordi, 2004. Shocking aspects of European enlargement. Eastern European Economics, $42,36-57$.

Rose, Andrew K., Stanley, T. D., 2005. A meta analysis of the effect of common currencies on international trade. Journal of Economic Surveys 19, 347-365.

Stanley, T. D., 2001. Wheat from chaff: Meta-analysis as quantitative literature review. Journal of Economic Perspectives 15, 131-150.

Stanley, T. D., Jarrell, Stephen B., 2005. Meta regression analysis: A quantitative method of literature surveys, Journal of Economic Surveys 19, 299-308.

Süppel, Ralph, 2003. Comparing economic dynamics in the EU and CEE accession countries. Working Paper No. 267. ECB, Frankfurt am Main.

Traistaru, Iulia, 2004. Transmission channels of business cycles synchronization in an enlarged EMU. Working Paper No. B18. Center for European Integration Studies, ZEI, Bonn. 


\section{CESifo Working Paper Series}

(for full list see www.cesifo-group.de)

1633 Michiel Evers, Ruud A. de Mooij and Daniel J. van Vuuren, What Explains the Variation in Estimates of Labour Supply Elasticities?, December 2005

1634 Matthias Wrede, Health Values, Preference Inconsistency, and Insurance Demand, December 2005

1635 Hans Jarle Kind, Marko Koethenbuerger and Guttorm Schjelderup, Do Consumers Buy Less of a Taxed Good?, December 2005

1636 Michael McBride and Stergios Skaperdas, Explaining Conflict in Low-Income Countries: Incomplete Contracting in the Shadow of the Future, December 2005

1637 Alfons J. Weichenrieder and Oliver Busch, Artificial Time Inconsistency as a Remedy for the Race to the Bottom, December 2005

1638 Aleksander Berentsen and Christopher Waller, Optimal Stabilization Policy with Flexible Prices, December 2005

1639 Panu Poutvaara and Mikael Priks, Violent Groups and Police Tactics: Should Tear Gas Make Crime Preventers Cry?, December 2005

1640 Yin-Wong Cheung and Kon S. Lai, A Reappraisal of the Border Effect on Relative Price Volatility, January 2006

1641 Stefan Bach, Giacomo Corneo and Viktor Steiner, Top Incomes and Top Taxes in Germany, January 2006

1642 Johann K. Brunner and Susanne Pech, Optimum Taxation of Life Annuities, January 2006

1643 Naércio Aquino Menezes Filho, Marc-Andreas Muendler and Garey Ramey, The Structure of Worker Compensation in Brazil, with a Comparison to France and the United States, January 2006

1644 Konstantinos Angelopoulos, Apostolis Philippopoulos and Vanghelis Vassilatos, RentSeeking Competition from State Coffers: A Calibrated DSGE Model of the Euro Area, January 2006

1645 Burkhard Heer and Bernd Suessmuth, The Savings-Inflation Puzzle, January 2006

1646 J. Stephen Ferris, Soo-Bin Park and Stanley L. Winer, Political Competition and Convergence to Fundamentals: With Application to the Political Business Cycle and the Size of Government, January 2006 
$1647 \mathrm{Yu}-\mathrm{Fu}$ Chen, Michael Funke and Kadri Männasoo, Extracting Leading Indicators of Bank Fragility from Market Prices - Estonia Focus, January 2006

1648 Panu Poutvaara, On Human Capital Formation with Exit Options: Comment and New Results, January 2006

1649 Anders Forslund, Nils Gottfries and Andreas Westermark, Real and Nominal Wage Adjustment in Open Economies, January 2006

1650 M. Hashem Pesaran, Davide Pettenuzzo and Allan G. Timmermann, Learning, Structural Instability and Present Value Calculations, January 2006

1651 Markku Lanne and Helmut Luetkepohl, Structural Vector Autoregressions with Nonnormal Residuals, January 2006

1652 Helge Berger, Jakob de Haan and Jan-Egbert Sturm, Does Money Matter in the ECB Strategy? New Evidence Based on ECB Communication, January 2006

1653 Axel Dreher and Friedrich Schneider, Corruption and the Shadow Economy: An Empirical Analysis, January 2006

1654 Stefan Brandauer and Florian Englmaier, A Model of Strategic Delegation in Contests between Groups, January 2006

1655 Jan Zápal and Ondřej Schneider, What are their Words Worth? Political Plans and Economic Pains of Fiscal Consolidations in New EU Member States, January 2006

1656 Thiess Buettner, Sebastian Hauptmeier and Robert Schwager, Efficient Revenue Sharing and Upper Level Governments: Theory and Application to Germany, January 2006

1657 Daniel Haile, Abdolkarim Sadrieh and Harrie A. A. Verbon, Cross-Racial Envy and Underinvestment in South Africa, February 2006

1658 Frode Meland and Odd Rune Straume, Outsourcing in Contests, February 2006

1659 M. Hashem Pesaran and Ron Smith, Macroeconometric Modelling with a Global Perspective, February 2006

1660 Alexander F. Wagner and Friedrich Schneider, Satisfaction with Democracy and the Environment in Western Europe - a Panel Analysis, February 2006

1661 Ben J. Heijdra and Jenny E. Ligthart, Fiscal Policy, Monopolistic Competition, and Finite Lives, February 2006

1662 Ludger Woessmann, Public-Private Partnership and Schooling Outcomes across Countries, February 2006

1663 Topi Miettinen and Panu Poutvaara, Political Parties and Network Formation, February 2006 
1664 Alessandro Cigno and Annalisa Luporini, Optimal Policy Towards Families with Different Amounts of Social Capital, in the Presence of Asymmetric Information and Stochastic Fertility, February 2006

1665 Samuel Muehlemann and Stefan C. Wolter, Regional Effects on Employer Provided Training: Evidence from Apprenticeship Training in Switzerland, February 2006

1666 Laszlo Goerke, Bureaucratic Corruption and Profit Tax Evasion, February 2006

1667 Ivo J. M. Arnold and Jan J. G. Lemmen, Inflation Expectations and Inflation Uncertainty in the Eurozone: Evidence from Survey Data, February 2006

1668 Hans Gersbach and Hans Haller, Voice and Bargaining Power, February 2006

1669 Françoise Forges and Frédéric Koessler, Long Persuasion Games, February 2006

1670 Florian Englmaier and Markus Reisinger, Information, Coordination, and the Industrialization of Countries, February 2006

1671 Hendrik Hakenes and Andreas Irmen, Something out of Nothing? Neoclassical Growth and the 'Trivial' Steady State, February 2006

1672 Torsten Persson and Guido Tabellini, Democracy and Development: The Devil in the Details, February 2006

1673 Michael Rauber and Heinrich W. Ursprung, Evaluation of Researchers: A Life Cycle Analysis of German Academic Economists, February 2006

1674 Ernesto Reuben and Frans van Winden, Reciprocity and Emotions when Reciprocators Know each other, February 2006

1675 Assar Lindbeck and Mats Persson, A Model of Income Insurance and Social Norms, February 2006

1676 Horst Raff, Michael Ryan and Frank Staehler, Asset Ownership and Foreign-Market Entry, February 2006

1677 Miguel Portela, Rob Alessie and Coen Teulings, Measurement Error in Education and Growth Regressions, February 2006

1678 Andreas Haufler, Alexander Klemm and Guttorm Schjelderup, Globalisation and the Mix of Wage and Profit Taxes, February 2006

1679 Kurt R. Brekke and Lars Sørgard, Public versus Private Health Care in a National Health Service, March 2006

1680 Dominik Grafenhofer, Christian Jaag, Christian Keuschnigg and Mirela Keuschnigg, Probabilistic Aging, March 2006 
1681 Wladimir Raymond, Pierre Mohnen, Franz Palm and Sybrand Schim van der Loeff, Persistence of Innovation in Dutch Manufacturing: Is it Spurious?, March 2006

1682 Andrea Colciago, V. Anton Muscatelli, Tiziano Ropele and Patrizio Tirelli, The Role of Fiscal Policy in a Monetary Union: Are National Automatic Stabilizers Effective?, March 2006

1683 Mario Jametti and Thomas von Ungern-Sternberg, Risk Selection in Natural Disaster Insurance - the Case of France, March 2006

1684 Ken Sennewald and Klaus Waelde, "Itô's Lemma" and the Bellman Equation for Poisson Processes: An Applied View, March 2006

1685 Ernesto Reuben and Frans van Winden, Negative Reciprocity and the Interaction of Emotions and Fairness Norms, March 2006

1686 Françoise Forges, The Ex Ante Incentive Compatible Core in Exchange Economies with and without Indivisibilities, March 2006

1687 Assar Lindbeck, Mårten Palme and Mats Persson, Job Security and Work Absence: Evidence from a Natural Experiment, March 2006

1688 Sebastian Buhai and Coen Teulings, Tenure Profiles and Efficient Separation in a Stochastic Productivity Model, March 2006

1689 Gebhard Kirchgaessner and Silika Prohl, Sustainability of Swiss Fiscal Policy, March 2006

1690 A. Lans Bovenberg and Peter Birch Sørensen, Optimal Taxation and Social Insurance in a Lifetime Perspective, March 2006

1691 Moritz Schularick and Thomas M. Steger, Does Financial Integration Spur Economic Growth? New Evidence from the First Era of Financial Globalization, March 2006

1692 Burkhard Heer and Alfred Maussner, Business Cycle Dynamics of a New Keynesian Overlapping Generations Model with Progressive Income Taxation, March 2006

1693 Jarko Fidrmuc and Iikka Korhonen, Meta-Analysis of the Business Cycle Correlation between the Euro Area and the CEECs, March 2006 